\title{
The ubiquitin proteasome system in Huntington's disease and the spinocerebellar ataxias
} Janet E Davies, Sovan Sarkar and David C Rubinsztein*

\author{
Address: ${ }^{1}$ Department of Medical Genetics, Cambridge Institute for Medical Research, Wellcome/MRC Building, Addenbrooke's Hospital, Hills \\ Road, Cambridge, CB2 2XY, UK \\ Email: David C Rubinsztein* - dcr1000@hermes.cam.ac.uk \\ * Corresponding author
}

Published: 22 November 2007

BMC Biochemistry 2007, 8(Suppl I):S2 doi:I0.II86/I47I-209I-8-SI-S2

This article is available from: http://www.biomedcentral.com/I47I-209I/8/SI/S2

(C) 2007 Davies et al.; licensee BioMed Central Ltd.

This is an open access article distributed under the terms of the Creative Commons Attribution License (http://creativecommons.org/licenses/by/2.0), which permits unrestricted use, distribution, and reproduction in any medium, provided the original work is properly cited.

\begin{abstract}
Huntington's disease and several of the spinocerebellar ataxias are caused by the abnormal expansion of a CAG repeat within the coding region of the disease gene. This results in the production of a mutant protein with an abnormally expanded polyglutamine tract. Although these disorders have a clear monogenic cause, each polyglutamine expansion mutation is likely to cause the dysfunction of many pathways and processes within the cell. It has been proposed that the ubiquitin proteasome system is impaired in polyglutamine expansion disorders and that this contributes to pathology. However, this is controversial with some groups demonstrating decreased proteasome activity in polyglutamine expansion disorders, some showing no change in activity and others demonstrating an increase in proteasome activity. It remains unknown whether the ubiquitin proteasome system is a feasible therapeutic target in these disorders. Here we review the conflicting results obtained from different assays performed in a variety of different systems.
\end{abstract}

Publication history: Republished from Current BioData's Targeted Proteins database (TPdb; http://www.targetedproteinsdb.com).

\section{Protein pathway in disease}

Nine neurodegenerative disorders are caused by the abnormal expansion of polyglutamine-encoding CAG repeat sequences: Huntington's disease (HD), spino-cerebellar ataxia (SCA) types 1, 2, 3, 6, 7 and 17, spinobulbar muscular atrophy and dentatorubral-pallidoluysian atrophy [1]. These disorders are generally inherited in an autosomal dominant manner (except for spinobulbar muscular atrophy, which is X-linked) and the underlying mutations are thought to act predominantly via toxic gain-of-function mechanisms [2]. Mutant proteins with expanded polyglutamine tracts form aggregates in the affected tissues [3-5]. Recently, polyglutamine-containing aggregates were reported in SCA 8 [6]. SCA 8 is caused by the expansion of a CTG repeat in the 3 ' end of the ataxin 8 gene, which was previously thought to be untranslated. The polyglutamine-containing protein associated with SCA 8 is now thought to be encoded by a previously unidentified antiparallel transcript spanning the repeat in the CAG direction [6].

HD and many of the dominant SCAs are caused by the expansion of a polyglutamine tract within the coding region of the huntingtin and ataxin genes, respectively. Although HD and the SCAs are caused by single mutations (the expansion of a CAG tract), the expression of a 
mutant protein containing a polyglutamine expansion is thought to have a variety of cellular consequences and elicit many pathogenic mechanisms. For example, in HD, mutant huntingtin has been proposed to cause the dysregulation of transcription [7], either through the interaction of transcription factors (e.g. CBP) with mutant huntingtin or by the polyglutamine expansion disrupting wild-type huntingtin's role in regulating transcription [8,9]. Wildtype huntingtin has been shown to bind repressor element-1 silencing transcription factor/neuron-restrictive silencer factor (REST/NRSF), sequester it in the cytosol and reduce its inhibitory effect on promoters containing neuron-restrictive silencing elements such as the BDNF promoter, thus increasing the production of BDNF. This control is lost in HD; there is a reduced interaction between mutant huntingtin and REST/NRSF, leading to a reduction in the production of BDNF [8,9]. Expression of mutant huntingtin has also been shown to cause excitotoxicity and damage mitochondria, leading to the increased generation of destructive oxygen free radicals and to alterations in energy production [10], disruption of transport along axons [11] and impairment of endocytosis and intracellular vesicle transport [12]. Although controversial, mutant huntingtin has also been proposed to impair the ubiquitin proteasome system (UPS) [13-15]. The polyglutamine expansion mutation is thought to cause disruption of the same systems and elicit similar pathogenic mechanisms in SCA [16].

The UPS is a major protein degradation pathway in cells, typically degrading short-lived and damaged proteins $[17,18]$. The proteasome also has a role in cell signalling, as it degrades many regulatory proteins, such as p53 and $\mathrm{IKKB}$, and protein subunits. Recently, it was proposed that the proteasome has a role in normal synaptic function and plasticity, and is involved in the NMDA-dependent remodelling of the protein composition of synapses [19]. Therefore, the proteasome not only represents a degradation pathway but is also a major regulator of normal cellular and physiological functioning. Impairment of the UPS will thus have considerable consequences on the cell and indeed the organism.

Two mechanisms have been proposed to account for the UPS impairment observed by some groups in polyglutamine expansion disorders. The first arises from the observation that polyglutamine aggregates in cell models, brains from HD transgenic mouse models and HD post mortem brains become labelled upon immunocytochemistry with antibodies against ubiquitin and proteasome subunits $[3,20,21]$, suggesting that the sequestration and altered subcellular localisation of UPS components could impair its normal function. However, inhibition of the proteasome has been demonstrated in cells co-expressing a GFP-degron construct (see Models, Knockouts and
Assays) and pathogenic huntingtin exon 1 constructs in the absence of visible aggregates [14]. In addition, there is some evidence to suggest that some molecules are not sequestered tightly into aggregates but are only loosely associated and can freely diffuse [22]. The second model comes from both in vitro and cell model data suggesting that expanded polyglutamine-containing proteins are not easily degraded by the eukaryotic proteasome, which can only accommodate unfolded proteins [23,24]. This model proposes that proteins containing expanded polyglutamine tracts may block the proteasome, thus preventing the entry of other substrates. Although it has been documented that synthetically generated polyglutamine aggregates do not inhibit 26S proteasome function in vitro[14], it has recently been shown that fibrillar species purified from HD transgenic mouse and human HD post mortem brains do decrease proteasome activity in vitro[25]. In addition, many of the wild-type ataxins have been shown to interact with components of the UPS. Yeast two-hybrid assays have demonstrated an interaction between ataxin-7 and the S4 subunit of the 19S proteasome [26], ataxin-1 and the ubiquitin-like protein A1Up [27], and ataxin-3 and the ubiquitin and proteasome binding factor HHR23B [28]. It has been proposed that these wild-type ataxins have a role in UPS function; thus it is possible that expansion of the polyglutamine repeats in these proteins may disrupt interactions with the UPS and compromise its function.

The impairment of the UPS in polyglutamine expansion disorders is controversial since some groups demonstrate a decrease in proteasome activity [13-15,29,30], some show no change in activity [31,32] and others demonstrate an increase in proteasome activity [33,34]. These conflicting results come from different assays performed in a variety of different systems [35] (which may indeed represent different stages of disease) and are discussed in more detail below.

\section{Models, knockouts and assays}

A variety of approaches have been used to study UPS function in polyglutamine expansion disorders (see Table 1) [36]. Each assay has advantages and disadvantages, and could be monitoring a different part of the UPS pathway. In addition, these assays have been used to assess UPS activity in different models (stable, inducible and transient cell models, transgenic Drosophila, transgenic mice and human post mortem samples, see Table 2). These models could represent different stages of the human disease, express the polyglutamine-containing protein at different levels under the control of different promoters, and in the case of Huntington's disease models, express huntingtin transgenes of different sizes (e.g. full length huntingtin or smaller exon 1 fragments). 
Table I: Assays used to study UPS function in polyglutamine expansion disorders. See text for further details.

\begin{tabular}{|c|c|c|c|c|c|}
\hline Method & Measures & $\begin{array}{l}\text { UPS component } \\
\text { assayed }\end{array}$ & Advantages & Disadvantage & Reference \\
\hline $\begin{array}{l}\text { Fluorogenic substrate } \\
\text { peptides }\end{array}$ & $20 \mathrm{~S}$ proteasome activity & $\begin{array}{l}\text { Direct measure of } \\
\text { chymotrypsin-like, trypsin- } \\
\text { like or peptidyl-glutamyl } \\
\text { activity of the } 20 \text { S } \\
\text { proteasome }\end{array}$ & $\begin{array}{l}\text { Quantitative analysis of } \\
\text { proteolytic activity in cell } \\
\text { and tissue lysates }\end{array}$ & $\begin{array}{l}\text { Does not measure } \\
\text { ubiquitylation, substrate } \\
\text { interaction, unfolding or } \\
\text { effects on other } \\
\text { components of the UPS } \\
\text { other than proteasome } \\
\text { activity }\end{array}$ & {$[14,15,25,30,32,33]$} \\
\hline $\begin{array}{l}\text { Degron-tagged } \\
\text { fluorescent proteins }\end{array}$ & $\begin{array}{l}\text { Levels of fluorescent reporter } \\
\text { protein tagged with a signal } \\
\text { targeting it for proteasome } \\
\text { degradation }\end{array}$ & $\begin{array}{l}\text { Proteasome activity and } \\
\text { targeting to proteasome }\end{array}$ & $\begin{array}{l}\text { Functional analysis of UPS } \\
\text { system in vivo }\end{array}$ & $\begin{array}{l}\text { Does not measure all } \\
\text { aspects of UPS function }\end{array}$ & {$[13,14,29,37,38]$} \\
\hline $\begin{array}{l}\text { Levels of endogenous UPS } \\
\text { substrates }\end{array}$ & $\begin{array}{l}\text { Degradation of well } \\
\text { characterised, endogenous } \\
\text { UPS substrates e.g. p53 }\end{array}$ & $\begin{array}{l}\text { Ubiquitylation, } \\
\text { proteasome activity, } \\
\text { chaperones }\end{array}$ & $\begin{array}{l}\text { Functional analysis of } \\
\text { entire UPS system. } \\
\text { Substrate expressed at } \\
\text { endogenous levels }\end{array}$ & $\begin{array}{l}\text { Levels of endogenous } \\
\text { substrate may be altered } \\
\text { due to effects of the } \\
\text { polyglutamine expansion } \\
\text { independent of the UPS }\end{array}$ & {$[15]$} \\
\hline Yeast two-hybrid assay & $\begin{array}{l}\text { Interaction of polyglutamine- } \\
\text { containing proteins with UPS } \\
\text { components }\end{array}$ & $\begin{array}{l}\text { Proteasome subunits and } \\
\text { components that interact } \\
\text { with polyglutamine } \\
\text { proteins }\end{array}$ & Shows direct interactions & $\begin{array}{l}\text { Does not give functional } \\
\text { data }\end{array}$ & [26-28] \\
\hline $\begin{array}{l}\text { In vitro assay of } \\
\text { proteasome activity }\end{array}$ & $\begin{array}{l}\text { Effect of synthetic peptides, } \\
\text { purifed aggregates and fibrillar } \\
\text { species on activity of purified } \\
\text { proteasomes }\end{array}$ & $\begin{array}{l}\text { Activity of purified } \\
\text { proteasomes }\end{array}$ & $\begin{array}{l}\text { Shows direct effects of } \\
\text { poly-glutamine containing } \\
\text { proteins on proteasome } \\
\text { activity }\end{array}$ & $\begin{array}{l}\text { Does not measure other } \\
\text { components of the UPS }\end{array}$ & {$[14,23-25]$} \\
\hline
\end{tabular}

Proteasome activity can be monitored by the proteolysis of small fluorogenic substrates specific for the chymotrypsin-like, trypsin-like or peptidyl-glutamyl activity of the 20S proteasome. These have been used to measure activity in lysates from neuro2A cells stably expressing $\mathrm{N}$ terminal huntingtin with an expanded polyglutamine tract [15], SH-SY5Y stably expressing polyglutaminegreen fluorescent protein constructs [32], transgenic mice [33], human HD post-mortem brains and patient skin fibroblasts [30]. These peptides have also been used to measure the activity of purified 26S proteasomes incubated with either synthetic polyglutamine-containing proteins [14] or aggregates and filaments purified from transgenic mice and human brains [25]. One issue with assays of isolated proteasome activity is that modest changes in proteasome number/activity may not be rate- limiting for substrate clearance. It is likely that ubiquitin conjugation and, in some situations, transport of ubiquitylinated proteins to the proteasome could be more important physiological regulators.

This problem has been partially addressed by measuring proteasome activity using reporter molecules comprising a fluorescent protein (e.g. enhanced green fluorescence protein (EGFP)) fused to a short sequence that targets the protein for proteasome degradation (termed a degron), $[13,14,29,37,38])$. This approach was initially used to generate a HeLa cell line stably expressing a reporter consisting of a short degron, CL1, fused to the carboxy-terminus of EGFP [13]. More recently, transgenic mice expressing EGFP tagged to a degron [38] and Caenorhabditis elegans expressing a ubiquitin-conjugated dsRed

Table 2: Model systems used to study UPS function in polyglutamine expansion disorders. See text for further details.

\begin{tabular}{|c|c|c|c|}
\hline Model & Methods used in conjunction & Additional notes & Reference \\
\hline Human post mortem brain & $\begin{array}{l}\text { Immunocytochemistry, assay of proteasome } \\
\text { activity in lysates using fluorescent substrates }\end{array}$ & & {$[3,20,30]$} \\
\hline Human patient skin fibroblasts & $\begin{array}{l}\text { Proteasome activity using fluorescent } \\
\text { substrates }\end{array}$ & & [30] \\
\hline $\mathrm{R} 6 / 2$ transgenic mouse model of $\mathrm{HD}$ & Proteasome activity, immunocytochemistry, & R6/2 mouse generated by Mangiarini et al. [60] & {$[21,34]$} \\
\hline R6/I transgenic mouse model of HD & Proteasome activity & R6/I mouse generated by Mangiarini et al. [60] & {$[15]$} \\
\hline HD94 conditional mouse model of HD & $\begin{array}{l}\text { Chymotrypsin-like, trypsin-like or peptidyl- } \\
\text { glutamyl activity in lysates }\end{array}$ & $\begin{array}{l}\text { HD94 conditional mouse generated by Yamamoto et al. } \\
{[6 \mathrm{I}]}\end{array}$ & [33] \\
\hline SCA 7 knock-in mouse model & $\begin{array}{l}\text { Crossed to a transgenic mouse expressing an } \\
\text { EGFP-degron reporter }\end{array}$ & SCA 7 transgenic mouse generated by Yoo et al. [62] & {$[31]$} \\
\hline $\begin{array}{l}\text { Transgenic Drosophila models of } \\
\text { polyglutamine expansion disorders }\end{array}$ & Genetic screens & & {$[56]$} \\
\hline $\begin{array}{l}\text { Cell models of HD and SCA, stable cell } \\
\text { lines and transient expression of mutant } \\
\text { constructs. Inducible or constitutive } \\
\text { transgene expression }\end{array}$ & $\begin{array}{l}\text { Immunocytochemistry, assay of proteasome } \\
\text { activity in lysates using fluorescent substrates, } \\
\text { co-expression of construct with fluorescent- } \\
\text { degron reporter. }\end{array}$ & & {$[13-15,20,29,32]$} \\
\hline C. elegans models & $\begin{array}{l}\text { Co-expression of mutant ataxin-3 and a } \\
\text { ubiquitin-conjugated dsRed reporter }\end{array}$ & & {$[37]$} \\
\hline
\end{tabular}


reporter [37] have been generated. It is also possible to monitor activity of the UPS by quantifying the levels and the degradation of well known proteasome substrates such as p53 [15].

\section{Disease targets and ligands}

The idea that the UPS may be impaired in polyglutamine expansion disorders initially came from studies showing the labelling of polyglutamine aggregates with antibodies raised against ubiquitin and proteasome subunits in cell models [20,39], transgenic mice [21] and human post mortem samples [3]. It was suggested that the sequestration of UPS components in aggregates and the altered subcellular localisation of proteasomes could affect UPS activity. The first study to assess proteasome activity used fluorogenic substrates [15]. A shift in chymotrypsin-like activity was demonstrated from cytosolic fractions to aggregate-containing, precipitated fractions derived from lysates from both a stable HD cell model (expressing huntingtin exon 1 with a 150 polyglutamine repeat) and brain lysates derived from R6/1 mice (expressing exon 1 of the huntingtin gene with a $(\mathrm{CAG})_{116}$ repeat expansion under control of the huntingtin promoter) [15]. Chymotrypsin-like activity was reduced in the cytosolic fraction and increased in precipitated fractions derived from these lysates when compared with control cells. This suggested the altered localisation of proteasomes to aggregates. The authors also demonstrated reduced degradation of p53. This study suggested an impairment of the UPS in HD. Soon after, this data was further supported by a study using an EGFP-degron reporter [13]. When this reporter was co-expressed with mutant huntingtin in cells, GFP fluorescence was increased more than two-fold when compared with cells expressing wild-type huntingtin. This observation implies a major impairment of proteasome function since a greater than $50 \%$ decrease in chymotrypsin-like activity is required to obtain a $50 \%$ increase in GFP fluorescence [13]. Similar results were found with the $\Delta 508$ mutant cystic fibrosis membrane conductance regulator (a protein that is unrelated to mutant huntingtin and the ataxins, sharing only the propensity to aggregate), suggesting that proteasome impairment is caused by aggregate formation [13]. Similarly, an EGFP reporter containing PEST sequences that target cytosolic proteins for proteasome degradation has been used to monitor proteasome activity in cells expressing ataxin-1 constructs [29]; the polyglutamine expansion mutation in ataxin 1 reduced activity of this assay. Consistent with these data, a reduction of chymotrypsin-like and peptidyl-glutamyl activity has been demonstrated in lysates from human HD post mortem brains and HD patient skin fibroblasts [30]. Similarly, inhibition of proteasome activity by ataxin-3 with an expanded CAG tract has been demonstrated in $C$. elegans using an EGFP-degron reporter [37].
Using the co-expression of NLS- or NES-tagged EGFPdegrons and NES or NLS mutant polyglutamine constructs, a global impairment of the UPS was demonstrated, regardless of the intracellular locations of the proteins containing the expanded polyglutamine tracts or the degron reporters [14]. Bennett et al. also disproved two hypotheses proposing mechanisms for the inhibition of proteasome activity. Contrary to the sequestration hypothesis, they demonstrated proteasome inhibition in the absence of visible aggregates. They also showed that synthetic protein aggregates do not inhibit activity of the 26S proteasome function in vitro suggesting that UPS impairment is unlikely to be caused by blocking of the proteasome. Indeed, the decreases in nuclear proteasome function by extra-nuclear mutant polyglutamine and vice versa argued that the observed effects were independent of interactions between mutant protein and the proteasome. However, it has recently been demonstrated that, whilst aggregates do not inhibit the proteasome, fibrillar forms of huntingtin purified from transgenic mouse and human post mortem brains do inhibit the $26 \mathrm{~S}$ proteasome in vitro [25].

Data contrary to the above, suggesting that the proteasome is not impaired in polyglutamine expansion disorders, comes from a variety of sources. SH-SY5Y cells stably expressing mutant huntingtin do not show a difference in the degradation of fluorogenic peptides, compared with cells expressing wild-type huntingtin [32].

More recently, an increase in the chymotrypsin-like and trypsin-like activities of the proteasome was observed in lysates derived from the cortex and striatum of the HD94 conditional mouse model of HD [33]. This was attributed to an increase in the levels of the proteasome subunits LMP2 and LMP7, and to the induction of the immunoproteasome. Immunoproteasomes are generally induced as part of the immune response (i.e. by interferongamma) and possess subunit composition and cleavage specificity favouring the production of peptides suitable for antigen presentation. Increased proteasomal chymotrypsin-like activity has also been observed in brain lysates from the R6/2 model of HD in comparison to non-transgenic littermates [34]. However, this study also demonstrates no change in overall $26 \mathrm{~S}$ proteasome activity and shows that the nuclear proteasome activator REG $\gamma$ is not involved in polyglutamine pathology, thus discounting it as a therapeutic target [34].

One of the caveats of studies in cell culture is that they express artificially high levels of mutant proteins. The role of the proteasome in vivo has recently been tested using the knock-in mouse model of SCA 7 crossed to a transgenic mouse expressing an EGFP-degron reporter [31]. Bowman et al. observed an increase in levels of the 
reporter in neurons at late stages of the disease. However, this was not due to inhibition of proteasome activity but correlated with an increase in mRNA encoding the EGFPdegron reporter. This study raises the important point that one should check that transcription of this in vivo reporter is not perturbed when its steady state level changes, otherwise one may in certain instances incorrectly ascribe accumulations to proteasome dysfunction.

It must be ascertained whether UPS activity is impaired in polyglutamine expansion disorders before the UPS is proposed as a therapeutic target. However, two groups have filed patents on the use of UPS modulators to treat neurodegenerative disorders (see additional file 1 for current patents relating to the UPS in Huntington's disease and the spinocerebellar ataxias). Based on the evidence that the proteasome is compromised in HD, Thompson, Marsh and Steffan have patented methods and reagents for reducing polyglutamine toxicity (no applicant listed), and Ramesh and Sean (ALS Therapy Development Foundation) have patented the use of proteasome modulators to treat neurodegenerative disorders. Lindquist and Duennwald (Whitehead Institute for Biomedical Research) have patented a method of screening for inhibitors of huntingtin-induced UPS impairment.

Mutations in parkin, a ubiquitin E3 ligase, lead to autosomal recessive Parkinson's disease. Parkin deficiency makes post-mitotic neurons more susceptible to excitotoxicty, whilst parkin over-expression protects neurons from kainate excitotoxicity and cell death [40]. Parkin also co-localises with mutant huntingtin aggregates in HD mice and human brains, and overexpression of parkin enhances the clearance of the mutant proteins [41]. Therefore, parkin is a feasible target for both the protection of post-mitotic neurons from excitotoxicity and the treatment of polyglutamine disorders by enhancing the clearance of toxic polyglutamine-containing proteins. Abeliovich and Staropoli (Columbia University) have patented parkin for this use.

There is evidence to suggest that polyglutamine-containing proteins are not efficiently degraded by the proteasome and even directly inhibit activity of the UPS [23-25]. Therefore, glutamine dipeptides, tripeptides or polypeptides have been patented by Goldberg (Harvard University) as bacterial proteasome inhibitors for the treatment of diseases such as those caused by Mycobacterium tuberculosis. Mycobacterium tuberculosis is highly resistant to killing by human macrophages, a property thought to be conferred by its proteasome [42]. Thus, inhibiting proteasome activity may attenuate this resistance.

\section{New frontiers in drug discovery}

One strategy for the treatment of polyglutamine expansion disorders is to decrease levels of the toxic mutant protein. This could be achieved by increasing the clearance of the mutant protein. Indeed, induction of autophagy by treatment with the mTOR inhibitor rapamycin has been demonstrated to reduce aggregation and increase survival in HD cell and mouse models [43]. Autophagy is also beneficial in SCA 3 and is generally neuroprotective $[44,45]$.

It is unclear whether proteins with an expanded polyglutamine tract are good proteasome substrates. Huntingtin interacts with the human ubiquitin-conjugating enzyme E2-25K, which requires the polyglutamine domain [46]. As previously described, parkin, an E3 ubiquitin ligase, also co-localises with mutant huntingtin aggregates in HD mice and human brains, and overexpression of parkin enhances the clearance of the mutant protein [41]. These data suggest that huntingtin may be a proteasome substrate. Consistent with this, proteasome inhibitors such as lactacystin and epoxomycin prevent mutant huntingtin clearance in a conditional HD mouse model or cell models after its expression is stopped [47].

Lactacystin, a microbial metabolite, was initially discovered and isolated from actinomycetes on the basis of its ability to induce neurite outgrowth in a murine neuroblastoma cell line [48]. Subsequent work demonstrated that the biological effects of lactacystin resulted from its ability to inhibit the proteasome [49]. Similarly, epoxomycin was isolated from a strain of actinomycetes and shown to exhibit potent anti-tumour and anti-inflammatory effects [50]. The target of epoxomycin was later shown to be the proteasome [51]. An increase in mutant huntingtin aggregation and toxicity in HD cell models after proteasome inhibition has also been demonstrated $[15,39,47,52,53]$. Likewise, aggregation of polyglutamine-expanded ataxin-1 and ataxin-3 is also increased after proteasome inhibition [54,55]. Furthermore, mutations in the genes encoding ubiquitin, ubiquitin C-terminal hydrolase, ubiquitin conjugase homologous to human UbcE2D2 and ubiquitin conjugase homologous to human Ubc2EH enhance polyglutamine toxicity in Drosophila over-expressing mutant ataxin-1 [56]. However, the proteasome is only able to accommodate unfolded proteins and it has been demonstrated that soluble mutant polyglutamine proteins are degraded by the proteasome whereas the aggregated form is resistant to degradation [57]. Likewise, the mutant form of ataxin-1 is more resistant to degradation in vitro than the wild-type form, although both the proteins are equally ubiquitylated [55]. 
Recently, it has been suggested that the proteasome is unable to cleave between glutamine residues within polyglutamine tracts $[23,24]$. Thus, if one could upregulate proteasome activity, one would possibly reduce the levels of proteins with polyglutamine expansions and associated flanking sequences. However, this would produce increased levels of long isolated polyglutamine tracts and such products are predicted to be more toxic than the inputs that have flanking sequences. Nevertheless, these long polyglutamine tracts are almost certainly degraded by cytosolic and nuclear peptidases, since moderate polyglutamine stretches are not uncommon in mammalian proteomes. It is unclear if the substrate capacity of such peptidases could be overwhelmed if proteasome activity were increased. In addition, modulation of the proteasome may not be a good therapeutic strategy. The proteasome has a key regulatory role and altering its rate of degradation could have many side effects. One may be able to use chemical chaperones such as trehalose or Congo red to increase the degradation of polyglutaminecontaining proteins, as these agents shift the equilibrium towards increasing the levels of soluble, monomeric proteasome-accessible species and away from aggregates $[58,59]$.

Further studies are required to resolve the conflicting data on UPS function in polyglutamine expansion disorders. It is possible that more attention should be paid to measuring levels of known endogenous proteasome substrates in vivo to test this important hypothesis. The differences in UPS activity seen in different models using a variety of assays must be explained before the UPS is proposed as a therapeutic target in HD and SCA.

\section{Notes added in proof}

Goldberg and colleagues have identified the peptidase downstream of the proteasome that degrades polyglutamine tracts as putomycin sensitive aminopeptidase [63].

In order to try to address if the proteasome is affected by mutant huntingtin in vivo, Kopito and colleagues measured levels of polyubiquitin chains as an endogenous biomarker [64]. The amount of polyubiquitin chains within a cell was shown be a faithful indicator of ubiquitin proteasome system function and elevated levels of polyubiquitin chains were demonstrated in brain lysates from R6/2 HD transgenic mice, the HdhQ150/Q150 knockin model of HD, and human HD post-mortem brains. One question raised by this study is whether the elevated levels of ubiquitin chains are necessarily due to proteasome dysfunction, as opposed to an increase in the ubiquitylation rate of substrates.

\section{Abbreviations}

UPS, ubiquitin proteasome system; HD, Huntington's disease; SCA, spinocerebellar ataxia; EGFP, enhanced green fluorescent protein.

\section{Competing interests}

David Rubinsztein and Sovan Sakar are inventors on patents relating to the use of autophagy upregulation for the treatment of neurodegenerative diseases. The Rubinsztein lab receives some research grant funding from Wyeth who make rapamycins.

\section{Additional material}

\section{Additional file 1}

Current patents relating to the ubiquitin proteasome system in Huntington's disease and the spinocerebellar ataxias. Despite controversy over the role of the UPS in the pathology of HD and the SCAs, several groups have filed patents on the use and screening of UPS modulators to treat neurodegenerative disorders. Whilst it remains to be seen whether UPS activity is impaired in polyglutamine disorders, these patents represent exciting potential therapeutic strategies.

Click here for file

[http://www.biomedcentral.com/content/supplementary/14712091-8-S1-S2-S1.doc]

\section{Acknowledgements}

The authors are funded by the Wellcome Trust (Senior Clinical Fellowship to $D C R$ ), the MRC (programme grant to DCR with S.Brown) and the Muscular Dystrophy Campaign, UK (DCR).

This article has been published as part of BMC Biochemistry Volume 8 Supplement I, 2007: Ubiquitin-Proteasome System in Disease Part I. The full contents of the supplement are available online at http://www.biomedcen tral.com/ $/ 47|-209| / 8$ ? issue $=$ SI .

\section{References}

I. Gusella JF, MacDonald ME: Molecular genetics: unmasking polyglutamine triggers in neurodegenerative disease. Nat Rev Neurosci 2000, I(2): 109-1I5.

2. Rubinsztein DC: How does the Huntington's disease mutation damage cells? Sci Aging Knowledge Environ 2003, 2003(37):PE26.

3. DiFiglia M, Sapp E, Chase KO, Davies SW, Bates GP, Vonsattel JP, Aronin N: Aggregation of huntingtin in neuronal intranuclear inclusions and dystrophic neurites in brain. Science 1997, 277(5334): 1990-1993.

4. Paulson HL, Perez MK, Trottier Y, Trojanowski JQ, Subramony SH, Das SS, Vig P, Mandel JL, Fischbeck KH, Pittman RN: Intranuclear inclusions of expanded polyglutamine protein in spinocerebellar ataxia type 3. Neuron 1997, 19(2):333-344.

5. Taylor JP, Hardy J, Fischbeck KH: Toxic proteins in neurodegenerative disease. Science 2002, 296(5575):199|-1995.

6. Moseley ML, Zu T, Ikeda Y, Gao W, Mosemiller AK, Daughters RS, Chen G, Weatherspoon MR, Clark HB, Ebner TJ, et al.: Bidirectional expression of CUG and CAG expansion transcripts and intranuclear polyglutamine inclusions in spinocerebellar ataxia type 8. Nat Genet 2006, 38(7):758-769.

7. Sugars KL, Rubinsztein DC: Transcriptional abnormalities in Huntington disease. Trends Genet 2003, 19(5):233-238.

8. Zuccato C, Ciammola A, Rigamonti D, Leavitt BR, Goffredo D, Conti L, MacDonald ME, Friedlander RM, Silani V, Hayden MR, et al.: Loss 
of huntingtin-mediated BDNF gene transcription in Huntington's disease. Science 200I, 293(5529):493-498.

9. Zuccato C, Tartari M, Crotti A, Goffredo D, Valenza M, Conti L, Cataudella $T$, Leavitt BR, Hayden MR, Timmusk $T$, et al:: Huntingtin interacts with REST/NRSF to modulate the transcription of NRSE-controlled neuronal genes. Nat Genet 2003, 35(I):76-83.

10. Beal MF: Mitochondria take center stage in aging and neurodegeneration. Ann Neurol 2005, 58(4):495-505.

II. Gunawardena S, Her LS, Brusch RG, Laymon RA, Niesman IR, Gordesky-Gold B, Sintasath L, Bonini NM, Goldstein LS: Disruption of axonal transport by loss of huntingtin or expression of pathogenic polyQ proteins in Drosophila. Neuron 2003, 40(I):25-40

12. Singaraja RR, Hadano S, Metzler M, Givan S, Wellington CL, Warby S, Yanai A, Gutekunst CA, Leavitt BR, Yi H, et al.: HIPI4, a novel ankyrin domain-containing protein, links huntingtin to intracellular trafficking and endocytosis. Hum Mol Genet 2002, I I(23):28I5-2828.

13. Bence NF, Sampat RM, Kopito RR: Impairment of the ubiquitinproteasome system by protein aggregation. Science 200I, 292(552I): I552-1555.

14. Bennett EJ, Bence NF, Jayakumar R, Kopito RR: Global impairment of the ubiquitin-proteasome system by nuclear or cytoplasmic protein aggregates precedes inclusion body formation. Mol Cell 2005, I 7(3):35I-365.

15. Jana NR, Zemskov EA, Wang G, Nukina N: Altered proteasomal function due to the expression of polyglutamine-expanded truncated $\mathrm{N}$-terminal huntingtin induces apoptosis by caspase activation through mitochondrial cytochrome c release. Hum Mol Genet 200I, I (1 (10): 1049-1059.

16. Duenas AM, Goold R, Giunti P: Molecular pathogenesis of spinocerebellar ataxias. Brain 2006, I29(Pt 6): 1357-1370.

17. Ciechanover A: Intracellular protein degradation: from a vague idea thru the lysosome and the ubiquitin-proteasome system and onto human diseases and drug targeting. Exp Biol Med (Maywood) 2006, 23 I(7): | | 97-I2II.

18. Goldberg AL: Protein degradation and protection against misfolded or damaged proteins. Nature 2003, 426(6968):895-899.

19. Bingol B, Schuman EM: Activity-dependent dynamics and sequestration of proteasomes in dendritic spines. Nature 2006, 44 I(7097): I I44-I I 48.

20. Cummings C], Mancini MA, Antalffy B, DeFranco DB, Orr HT, Zoghbi $H Y$ : Chaperone suppression of aggregation and altered subcellular proteasome localization imply protein misfolding in SCAI. Nat Genet 1998, 19(2):148-154.

21. Davies SW, Turmaine M, Cozens BA, Difiglia M, Sharp AH, Ross CA, Scherzinger E, Wanker EE, Mangiarini L, Bates GP: Formation of neuronal intranuclear inclusions underlies the neurological dysfunction in mice transgenic for the HD mutation. Cell 1997, 90(3):537-548.

22. Kim S, Nollen EA, Kitagawa K, Bindokas VP, Morimoto RI: Polyglutamine protein aggregates are dynamic. Nat Cell Biol 2002, 4(10):826-83I.

23. Holmberg Cl, Staniszewski KE, Mensah KN, Matouschek A, Morimoto RI: Inefficient degradation of truncated polyglutamine proteins by the proteasome. Embo / 2004, 23(2I):4307-43 I8.

24. Venkatraman P, Wetzel R, Tanaka M, Nukina N, Goldberg AL: Eukaryotic proteasomes cannot digest polyglutamine sequences and release them during degradation of polyglutamine-containing proteins. Mol Cell 2004, I 4(I):95-104.

25. Diaz-Hernandez M, Valera AG, Moran MA, Gomez-Ramos P, AlvarezCastelao B, Castano JG, Hernandez F, Lucas JJ: Inhibition of 26S proteasome activity by huntingtin filaments but not inclusion bodies isolated from mouse and human brain. J Neurochem 2006

26. Matilla A, Gorbea C, Einum DD, Townsend J, Michalik A, van Broeckhoven $\mathrm{C}$, Jensen CC, Murphy KJ, Ptacek LJ, Fu YH: Association of ataxin-7 with the proteasome subunit $\mathrm{S} 4$ of the $19 \mathrm{~S}$ regulatory complex. Hum Mol Genet 200I, I 0(24):282I-283I.

27. Davidson JD, Riley B, Burright EN, Duvick LA, Zoghbi HY, Orr HT: Identification and characterization of an ataxin- I-interacting protein: AIUp, a ubiquitin-like nuclear protein. Hum Mol Genet 2000, 9(15):2305-23।2.

28. Nicastro G, Menon RP, Masino L, Knowles PP, McDonald NQ, Pastore $A$ : The solution structure of the Josephin domain of ataxin-3: structural determinants for molecular recognition. Proc Natl Acad Sci U S A 2005, I02(30): 10493- 10498.

29. Park Y, Hong S, Kim SJ, Kang S: Proteasome function is inhibited by polyglutamine-expanded ataxin-I, the SCAI gene product. Mol Cells 2005, 19(I):23-30.

30. Seo H, Sonntag KC, Isacson O: Generalized brain and skin proteasome inhibition in Huntington's disease. Ann Neurol 2004, 56(3):319-328.

31. Bowman AB, Yoo SY, Dantuma NP, Zoghbi HY: Neuronal dysfunction in a polyglutamine disease model occurs in the absence of ubiquitin-proteasome system impairment and inversely correlates with the degree of nuclear inclusion formation. Hum Mol Genet 2005, 14(5):679-691.

32. Ding Q, Lewis JJ, Strum KM, Dimayuga E, Bruce-Keller AJ, Dunn JC, Keller JN: Polyglutamine expansion, protein aggregation, proteasome activity, and neural survival. I Biol Chem 2002, 277(16): | 3935-13942.

33. Diaz-Hernandez M, Hernandez F, Martin-Aparicio E, Gomez-Ramos P, Moran MA, Castano JG, Ferrer I, Avila J, Lucas JJ: Neuronal induction of the immunoproteasome in Huntington's disease. Neurosci 2003, 23(37): I 1653-II66I.

34. Bett JS, Goellner GM, Woodman B, Pratt G, Rechsteiner M, Bates GP: Proteasome impairment does not contribute to pathogenesis in R6/2 Huntington's disease mice: exclusion of proteasome activator REGgamma as a therapeutic target. Hum Mol Genet 2006, I5(I):33-44

35. Valera AG, Diaz-Hernandez M, Hernandez F, Ortega Z, Lucas J]: The ubiquitin-proteasome system in Huntington's disease. Neuroscientist 2005, I I (6):583-594.

36. Lindsten K, Dantuma NP: Monitoring the ubiquitin/proteasome system in conformational diseases. Ageing Res Rev 2003, 2(4):433-449. Good review of methods to study UPS activity

37. Khan LA, Bauer PO, Miyazaki H, Lindenberg KS, Landwehrmeyer BG, Nukina N: Expanded polyglutamines impair synaptic transmission and ubiquitin-proteasome system in Caenorhabditis elegans. J Neurochem 2006, 98(2):576-587.

38. Lindsten K, Menendez-Benito V, Masucci MG, Dantuma NP: A transgenic mouse model of the ubiquitin/proteasome system. Nat Biotechnol 2003, 2 I (8):897-902.

39. Wyttenbach A, Carmichael J, Swartz J, Furlong RA, Narain Y, Rankin J, Rubinsztein DC: Effects of heat shock, heat shock protein $\mathbf{4 0}$ (HDJ-2), and proteasome inhibition on protein aggregation in cellular models of Huntington's disease. Proc Natl Acad Sci U S A 2000, 97(6):2898-2903.

40. Staropoli JF, McDermott C, Martinat C, Schulman B, Demireva E, Abeliovich A: Parkin is a component of an SCF-like ubiquitin ligase complex and protects postmitotic neurons from kainate excitotoxicity. Neuron 2003, 37(5):735-749.

4I. Tsai YC, Fishman PS, Thakor NV, Oyler GA: Parkin facilitates the elimination of expanded polyglutamine proteins and leads to preservation of proteasome function. I Biol Chem 2003, 278(24):22044-22055.

42. Darwin KH, Ehrt S, Gutierrez-Ramos JC, Weich N, Nathan CF: The proteasome of Mycobacterium tuberculosis is required for resistance to nitric oxide. Science 2003, 302(5652): $1963-1966$.

43. Ravikumar B, Vacher C, Berger Z, Davies JE, Luo S, Oroz LG, Scaravilli F, Easton DF, Duden R, O'Kane CJ, et al.: Inhibition of $\mathbf{m T O R}$ induces autophagy and reduces toxicity of polyglutamine expansions in fly and mouse models of Huntington disease. Nat Genet 2004, 36(6):585-595.

44. Berger Z, Ravikumar B, Menzies FM, Oroz LG, Underwood BR, Pangalos MN, Schmitt I, Wullner U, Evert BO, O'Kane C], et al: Rapamycin alleviates toxicity of different aggregate-prone proteins. Hum Mol Genet 2006, I 5(3):433-442.

45. Ravikumar B, Berger Z, Vacher C, O'Kane CJ, Rubinsztein DC: Rapamycin pre-treatment protects against apoptosis. Hum Mol Genet 2006, I 5(7):1209-1216

46. Kalchman MA, Graham RK, Xia G, Koide HB, Hodgson JG, Graham KC, Goldberg YP, Gietz RD, Pickart CM, Hayden MR: Huntingtin is ubiquitinated and interacts with a specific ubiquitin-conjugating enzyme. J Biol Chem 1996, 27 I(32): I9385-I9394.

47. Martin-Aparicio E, Yamamoto A, Hernandez F, Hen R, Avila J, Lucas $\mathrm{JJ}$ : Proteasomal-dependent aggregate reversal and absence of cell death in a conditional mouse model of Huntington's disease. J Neurosci 200I, 2 I (22):8772-878I. 
48. Omura S, Fujimoto T, Otoguro K, Matsuzaki K, Moriguchi R, Tanaka $\mathrm{H}$, Sasaki $Y$ : Lactacystin, a novel microbial metabolite, induces neuritogenesis of neuroblastoma cells. J Antibiot (Tokyo) 1991, 44(I): II3-II6.

49. Fenteany G, Standaert RF, Lane WS, Choi S, Corey EJ, Schreiber SL: Inhibition of proteasome activities and subunit-specific amino-terminal threonine modification by lactacystin. Science 1995, 268(52II):726-73I.

50. Hanada M, Sugawara K, Kaneta K, Toda S, Nishiyama Y, Tomita K, Yamamoto H, Konishi M, Oki T: Epoxomicin, a new antitumor agent of microbial origin. J Antibiot (Tokyo) 1992, 45(II): I746-I752.

5I. Sin N, Kim KB, Elofsson M, Meng L, Auth H, Kwok BH, Crews CM: Total synthesis of the potent proteasome inhibitor epoxomicin: a useful tool for understanding proteasome biology. Bioorg Med Chem Lett 1999, 9(15):2283-2288.

52. Ravikumar B, Duden R, Rubinsztein DC: Aggregate-prone proteins with polyglutamine and polyalanine expansions are degraded by autophagy. Hum Mol Genet 2002, II (9): I I07-I I I 7 .

53. Waelter S, Boeddrich A, Lurz R, Scherzinger E, Lueder G, Lehrach $H$, Wanker EE: Accumulation of mutant huntingtin fragments in aggresome-like inclusion bodies as a result of insufficient protein degradation. Mol Biol Cell 200I, I 2(5): I393-I 407.

54. Chai Y, Koppenhafer SL, Shoesmith SJ, Perez MK, Paulson HL: Evidence for proteasome involvement in polyglutamine disease: localization to nuclear inclusions in SCA3/MJD and suppression of polyglutamine aggregation in vitro. Hum Mol Genet 1999, 8(4):673-682

55. Cummings C], Reinstein E, Sun $Y$, Antalffy B, Jiang $Y$, Ciechanover A Orr HT, Beaudet AL, Zoghbi HY: Mutation of the E6-AP ubiquitin ligase reduces nuclear inclusion frequency while accelerating polyglutamine-induced pathology in SCAI mice. Neuron 1999, 24(4):879-892.

56. Fernandez-Funez P, Nino-Rosales ML, de Gouyon B, She WC, Luchak JM, Martinez P, Turiegano E, Benito J, Capovilla M, Skinner PJ, et al.: Identification of genes that modify ataxin- $I$-induced neurodegeneration. Nature 2000, 408(6808): $10 \mathrm{I}-106$.

57. Verhoef LG, Lindsten K, Masucci MG, Dantuma NP: Aggregate formation inhibits proteasomal degradation of polyglutamine proteins. Hum Mol Genet 2002, I I(22):2689-2700.

58. Davies JE, Sarkar S, Rubinsztein DC: Trehalose reduces aggregate formation and delays pathology in a transgenic mouse model of oculopharyngeal muscular dystrophy. Hum Mol Genet 2006, 15(I):23-31.

59. Sanchez I, Mahlke C, Yuan J: Pivotal role of oligomerization in expanded polyglutamine neurodegenerative disorders. Nature 2003, 42I(692I):373-379.

60. Mangiarini L, Sathasivam K, Seller M, Cozens B, Harper A, Hetherington C, Lawton M, Trottier Y, Lehrach H, Davies SW, et al.: Exon I of the HD gene with an expanded CAG repeat is sufficient to cause a progressive neurological phenotype in transgenic mice. Cell 1996, 87(3):493-506.

61. Yamamoto A, Lucas J], Hen R: Reversal of neuropathology and motor dysfunction in a conditional model of Huntington's disease. Cell 2000, I0I(I):57-66.

62. Yoo SY, Pennesi ME, Weeber EJ, Xu B, Atkinson R, Chen S, Armstrong DL, Wu SM, Sweatt JD, Zoghbi HY: SCA7 knockin mice model human SCA7 and reveal gradual accumulation of mutant ataxin-7 in neurons and abnormalities in short-term plasticity. Neuron 2003, 37(3):383-40I.

63. Bhutani NP, et al.: Puromycin-sensitive aminopeptidase is the major peptidase responsible for digesting polyglutamine sequences released by proteasomes during protein degradation. EMBO / 2007, 26(5): | 385-1396.

64. Bennett EJ, et al.: Global changes to the ubiquitin system in Huntington's disease. Nature 2007, 448(7 I 54):704-708.

\section{Publication history}

Republished from Current BioData's Targeted Proteins database (http://TPdb; www.targetedproteinsdb.com).
Publish with Bio Med Central and every scientist can read your work free of charge

"BioMed Central will be the most significant development for disseminating the results of biomedical research in our lifetime. "

Sir Paul Nurse, Cancer Research UK

Your research papers will be:

- available free of charge to the entire biomedical community

- peer reviewed and published immediately upon acceptance

- cited in PubMed and archived on PubMed Central

- yours - you keep the copyright

Submit your manuscript here:

http://www.biomedcentral.com/info/publishing_adv.asp
BioMedcentral 